\title{
Prevalence of gender-based and sexual harassment within orthopedic surgery in Canada
}

\author{
Victoria Giglio, MSc \\ Patricia Schneider, BSc \\ Zoe Bond, BSc \\ Kim Madden, PhD \\ Paula McKay, BSc \\ Anthony Bozzo, MD, MSc \\ Mohit Bhandari, MD, PhD \\ Michelle Ghert, MD
}

Presented at the Association of Bone and Join Surgeons annual meeting, April 7-11, 2020, Washington, DC, and the Canadian Orthopaedic Association annual meeting, June 1920, 2020, Halifax, NS

Accepted Feb. 9, 2021

\author{
Correspondence to: \\ M. Ghert \\ Hamilton Health Sciences \\ Juravinski Hospital and Cancer Centre \\ Level B3 Surgical Offices \\ 711 Concession St \\ Hamilton ON L8V 1C3 \\ ghertm@mcmaster.ca
}

Cite as: Can J Surg 2022 January 27; 65(1). doi: $10.1503 /$ cjs. 013120

\begin{abstract}
Background: Gender-based and sexual harassment are prevalent in the medical profession. We aimed to quantify the prevalence of such behaviours within orthopedic surgery in Canada and to identify any risk factors for experiencing gender-based or sexual harassment in the workplace.
\end{abstract}

Methods: In collaboration with the Canadian Orthopaedic Association, we conducted a Canada-wide email questionnaire survey in June 2019 of all orthopedic surgeons registered with the Canadian Orthopaedic Association and the Canadian Orthopaedic Residents' Association. The development of our questionnaire was informed by a review of the literature and published surveys on gender-based and sexual harassment, and consultation with researchers in intimate partner violence. We conducted a multivariable logistic regression analysis to identify risk factors for harassment.

Results: Of the 1783 surgeons invited to participate, 465 returned the questionnaire (response rate $26.1 \%$ ); the response rate was $48.1 \%$ for females and $22.1 \%$ for males. Overall, $331 / 433$ respondents $(76.4 \%$, 95\% confidence interval [CI] 72\%-80\%) and $315 / 423$ respondents $(74.5 \%, 95 \%$ CI $70 \%-78 \%)$ reported having experienced at least 1 occurrence of gender-based and sexual harassment, respectively. Women were significantly more likely than men to have experienced both gender-based and sexual harassment (odds ratio [OR] 16.2, 95\% CI 4.8-54.0, and OR 2.2, 95\% CI 1.2-4.0, respectively). Respondents who identified as nonwhite were significantly less likely than those who identified as white to have experienced gender-based harassment (OR $0.5,95 \%$ CI $0.3-0.99)$.

Conclusion: The prevalence of gender-based and sexual harassment is high within Canadian orthopedic surgery, and women are at highest risk for experiencing harassment. The results may provide the impetus for orthopedic societies to develop action plans and to re-examine and enforce policies to address these damaging behaviours appropriately.

Contexte : La discrimination et le harcèlement sexuels sont prévalents dans la profession médicale. Nous avons voulu mesurer la prévalence de ces comportements dans le milieu de la chirurgie orthopédique au Canada, et identifier les facteurs de risque liés à l'expérience de la discrimination et du harcèlement sexuels en milieu de travail.

Méthodes : En collaboration avec l'Association canadienne d'orthopédie, nous avons procédé à un sondage pancanadien par voie de courriels en juin 2019 auprès de tous les chirurgiens orthopédistes de l'Association canadienne d'orthopédie et de l'Association canadienne des résidents en orthopédie. Pour concevoir notre questionnaire, nous avons consulté une revue de la littérature et des sondages publiés sur la discrimination et le harcèlement sexuels et des chercheurs du domaine de la violence conjugale. Nous avons effectué une analyse de régression logistique multivariée pour identifier les facteurs de risque de harcèlement.

Résultats : Parmi les 1783 chirurgiens invités à participer, 465 ont retourné le questionnaire (taux de réponse $26,1 \%$ ); le taux de réponse a été de $48,1 \%$ chez les femmes et de $22,1 \%$ chez les hommes. En tout, $331 / 433$ répondeurs $(76,4 \%$, intervalle de confiance [IC] de $95 \% 72 \%-80 \%)$ et $315 / 423$ répondeurs $(74,5 \%$, IC de $95 \%$ $70 \%-78 \%)$ ont respectivement signalé avoir été victime de discrimination et de harcèlement sexuels à au moins 1 occasion. Les femmes étaient significativement plus susceptibles d'avoir subi de la discrimination et du harcèlement sexuels (rapport des cotes [RC] 16,2, IC de $95 \%$ 4,8-54,0, et RC 2,2, IC de $95 \% 1,2-4,0$, respectivement). Les répondeurs se disant non blancs étaient significativement moins susceptibles d'avoir été victimes de discrimination sexuelle que les répondeurs se disant blancs (RC 0,5 , IC de $95 \% 0,3-0,99$ ). 
Conclusion : La prévalence de la discrimination et du harcèlement sexuels est élevée dans le milieu de la chirurgie orthopédique au Canada et les femmes sont exposées au risque le plus élevé à cet égard. Ces conclusions devraient inciter les sociétés d'orthopédie à mettre sur pied des plans d'action ainsi qu'à revoir et appliquer des politiques pour s'attaquer à ces comportements de manière appropriée.

$\mathrm{H}$ arassment in the workplace can take many forms. Gender-based harassment is defined by the Ontario Human Rights Commission as "any behaviour that polices and reinforces traditional heterosexual gender norms." ${ }^{1}$ Sexual harassment is defined by the Government of Canada in the Canada Labour Code as "any conduct, comment, gesture or contact of a sexual nature that is likely to cause offence or humiliation to any employee; or that might, on reasonable grounds, be perceived by that employee as placing a condition of a sexual nature on employment or on any opportunity for training or promotion." Given the detrimental effects of gender-based and sexual harassment on both the person and the workplace as a whole, the World Health Organization has declared the elimination of gender-based violence, discrimination and harassment in the workplace as a priority in the global strategy for health in the workforce. ${ }^{3}$

Previous research has shown that gender-based harassment and sexual harassment are prevalent in the medical profession. Jagsi and colleagues ${ }^{4}$ reported that $30 \%$ of female faculty and $4 \%$ of male faculty in an academic medical setting had experienced sexual harassment. A recent systematic review and meta-analysis showed that discrimination, bullying and harassment are a major issue in surgical practice, with pooled estimates of $22.4 \%, 37.7 \%$ and $40.3 \%$, respectively, of people in surgical practice experiencing these behaviours. ${ }^{5}$ It has also been reported that exposure to gender discrimination and sexual harassment influenced medical specialty choices for $45.3 \%$ of women and $16.4 \%$ of men. ${ }^{6}$

Although the proportion of female physicians has increased greatly in the last several decades, ${ }^{7}$ proportionate growth within orthopedic surgery has not followed. ${ }^{8,9}$ In 2018, the Canadian Medical Association reported that only $12 \%$ of orthopedic surgeons were female, one of the lowest proportions of female representation in surgical specialties. ${ }^{10}$ An explanation for this enduring gender gap remains elusive. We aimed to quantify the prevalence of genderbased and sexual harassment over the career continuum of resident, fellow and staff surgeons in orthopedic surgery in Canada, and to identify any risk factors for experiencing such behaviour in the workplace.

\section{Methods}

\section{Design and setting}

We conducted a Canada-wide cross-sectional survey of all orthopedic surgeons registered with the Canadian Orthopaedic Association (COA) to assess the prevalence of gender-based and sexual harassment within orthopedic surgery. The study was done in collaboration with the COA. We previously published the protocol as a preprint (https:// osf.io/e $5 \mathrm{c} 6 \mathrm{n} /)$. The study was approved by the Hamilton Integrated Research Ethics Board (project \#4848).

For the purpose of this study, we defined gender-based harassment as occurring when

a person experiences discrimination or unequal treatment based on his or her gender or gender identity. The harassment does not need to be based on anything of a sexual nature. Instead, gender-based harassment involves stereotypes based on the traditional roles and functions associated with a gender.

\section{We defined sexual harassment as}

bullying or coercion of a sexual nature, or the unwelcome or inappropriate promise of rewards in exchange for sexual favours. Such harassment can include unwelcome sexual advances, requests for sexual favours, and other verbal or physical harassment of a sexual nature.

\section{Participants}

All levels of COA membership (trainees, practising surgeons and retirees) were eligible for inclusion. An email distribution list of all active members of the COA and the Canadian Orthopaedic Residents' Association was provided by the COA.

\section{Survey development}

We developed a questionnaire to assess the prevalence of gender-based and sexual harassment within orthopedic surgery. Our questionnaire was informed by a review of the current literature and published surveys on gender-based and sexual harassment, and incorporated aspects of preexisting questionnaires including the Sexual Experiences Questionnaire, the Sexual Experiences QuestionnaireDepartment of Defense and the Survey on Sexual Misconduct in the Canadian Armed Forces. ${ }^{11-13}$ In addition, we consulted researchers in the field of intimate partner violence (K.M., P.M., M.B.) who had previously surveyed patients on a similarly sensitive topic to provide guidance in the development of our questionnaire.

The draft questionnaire was reviewed by 3 health research methodology experts to ensure that nothing vital was missing, that the wording of the questions was clear, precise and relevant to the objectives of the study (content validity), and that the overall perception was that the questionnaire clearly addressed the issues involved (face validity). After revisions, we pilot tested the questionnaire with selected surgeons from 
other surgical specialties to ensure that all questions were straightforward and contained clear, widely recognized terminology (generalizable face and content validity). The questionnaire was revised based on the recommendations and retested until no additional issues or concerns were identified.

The final questionnaire comprised 116 items and consisted of Likert-scale questions, checkboxes and 3 brief openended questions (Appendix 1, available at www.canjsurg.ca/ lookup/doi/10.1503/cjs.013120/tab-related-content). It was divided into 4 sections: demographic characteristics and current education and work details; harassment in the workplace (separated into 2 parts: gender-based harassment and sexual harassment); behaviour details; and final thoughts and opinions. The prevalence of gender-based harassment was assessed in 6 questions investigating a variety of behaviours considered to be gender-based harassment, and the prevalence of sexual harassment was assessed by 14 questions investigating a variety of behaviours considered to be sexual harassment, both verbal/psychologic and physical.

\section{Survey administration}

We used the REDCap online survey tool to distribute the questionnaire online on June 17, 2019. This platform has several useful features, including the ability to individually email participants who have not yet completed the survey, while maintaining anonymity of questionnaire responses. We distributed the questionnaire via individual email invitations, providing concise details on the rationale for the study, the importance of participation, the anonymity process, and the potential benefits and harms of participation. Reminder emails were distributed up to 2 times after initial questionnaire distribution, at 3-week intervals.

Participants could save their responses and return to the questionnaire later if they were interrupted during survey completion. Given the sensitive nature of the study, participants could skip questions that they did not wish to answer and still remain in the study. The survey closed to further responses 9 weeks after the initial distribution. Completion of the questionnaire was voluntary, and consent was implied on submission.

\section{Statistical analysis}

To estimate the primary outcome of overall prevalence of gender-based harassment, we combined all positive answers to all questions on gender-based harassment. To estimate the primary outcome of overall prevalence of sexual harassment, we combined all positive answers to all questions on sexual harassment.

We analyzed the data using SPSS Version 25.0 (IBM Corp.). Primary outcomes are reported as percentages with associated $95 \%$ confidence intervals (CIs). To identify independent risk factors for the experience of gender-based or sexual harassment, we conducted a multivariable logistic regression analysis using a standard complete case analysis on the following demographic characteristics as independent variables: age, ethnicity, marital status, geographic region of residency and career stage. To protect anonymity, we omitted any analyses of all groups and subgroups that had fewer than 10 respondents. Risk factors are reported with odds ratios (ORs) with associated 95\% CIs.

\section{Results}

A total of 1783 people received an email to participate in the survey, 465 of whom completed the questionnaire for a response rate of $26.1 \%$. According to the sex categorization provided in the COA email distribution list, the response rate for females and males was $48.1 \%$ and $22.1 \%$, respectively. Of the 465 respondents, $334(71.8 \%)$ identified as men, $130(28.0 \%)$ as women, and $1(0.2 \%)$ as nonbinary (Table 1). The median age was 43 (interquartile range 35-59) years. Respondents were most commonly white $(375[80.6 \%])$ and married (356 [76.6\%]). Just over two-thirds (318 [68.4\%]) were staff orthopedic surgeons.

\begin{tabular}{|c|c|}
\hline Characteristic & $\begin{array}{c}\text { No. }(\%) \text { of } \\
\text { respondents* } \\
n=465\end{array}$ \\
\hline Age, median (IQR), yr $(n=454)$ & $43(35-59)$ \\
\hline \multicolumn{2}{|l|}{ Gender } \\
\hline Man & $334(71.8)$ \\
\hline Woman & $130(28.0)$ \\
\hline Nonbinary & $1(0.2)$ \\
\hline \multicolumn{2}{|l|}{ Race/ethnicity } \\
\hline African/Caribbean & $3(0.6)$ \\
\hline White & $375(80.6)$ \\
\hline East Asian & $24(5.2)$ \\
\hline Hispanic/Latino & $5(1.1)$ \\
\hline Middle Eastern & $19(4.1)$ \\
\hline Mixed & $11(2.4)$ \\
\hline Native/Aboriginal & $2(0.4)$ \\
\hline South Asian & $17(3.7)$ \\
\hline Other & $5(1.1)$ \\
\hline Missing & $4(0.9)$ \\
\hline \multicolumn{2}{|l|}{ Marital status } \\
\hline Common law & $28(6.0)$ \\
\hline Divorced & $12(2.6)$ \\
\hline Married & $356(76.6)$ \\
\hline Separated & $5(1.1)$ \\
\hline Single & $59(12.7)$ \\
\hline Widowed & $4(0.9)$ \\
\hline Missing & $1(0.2)$ \\
\hline \multicolumn{2}{|l|}{ Current occupation } \\
\hline Resident & $57(12.3)$ \\
\hline Fellow & $32(6.9)$ \\
\hline Staff & $318(68.4)$ \\
\hline Retired & $58(12.5)$ \\
\hline $\begin{array}{l}\text { IQR = interquartile range. } \\
{ }^{*} \text { Except where noted otherwise. }\end{array}$ & \\
\hline
\end{tabular}




\section{Prevalence of gender-based harassment}

Overall, the prevalence of gender-based harassment was high, with $331 / 433$ respondents $(76.4 \%$, 95\% CI $72 \%-80 \%)$ reporting having experienced at least 1 occurrence (Table 2). Almost all women (119/122 [97.5\%, 95\% CI 95\%-100\%]) reported experiencing such behaviour, compared to 211/ 310 men $(68.1 \%, 95 \%$ CI 63\%-73\%). Telling "offensive" (as worded in the questionnaire) jokes or making offensive remarks (by a supervisor, colleague or patient) was the most common gender-based harassment behaviour reported by all respondents (305/433 [70.4\%, 95\% CI 66\%-74\%]).

\section{Prevalence of sexual harassment}

The prevalence of sexual harassment was also high: 315/ 423 respondents $(74.5 \%, 95 \%$ CI 70\%-78\%) reported having experienced at least 1 occurrence (Table 2). The prevalence for women and men was 99/119 (83.2\%, 95\% CI $77 \%-90 \%)$ and $215 / 303$ (71.0\%, 95\% CI 66\%-76\%), respectively. Verbal/psychologic sexual harassment (304/423 [71.9\%, 95\% CI 68\%-76\%]) was more prevalent than physical sexual harassment (96/422 [22.7\%, 95\% CI $19 \%-27 \%]$ ). Making crude sexual remarks (by a supervisor, colleague or patient) was the most common verbal/ psychologic sexual harassment behaviour (270/423 [63.8\%, 95\% CI 59\%-69\%]), and uncomfortable physical contact from a supervisor, colleague or patient was the most common physical sexual harassment behaviour (83/420 [19.8\%, 95\% CI 16\%-24\%]).

\section{Reporting}

Of 291 respondents, 161 (55.3\%, 95\% CI 50\%-61\%) reported that a person in a position of authority was not informed about the harassment behaviour, and $79(27.1 \%$, $95 \%$ CI 22\%-32\%) were unsure whether the behaviour was reported. The most common reason why respondents did not report the behaviour was that they did not believe the issue was serious enough to report (103/240 [42.9\%, 95\% CI $37 \%-49 \%])$. Of the 51 respondents $(17.5 \%$, $95 \%$ CI $13 \%-$ $22 \%$ ) who informed a person in a position of authority about the behaviour, less than half $(25$ [49.0\%, 95\% CI 35\%$63 \%]$ ) were satisfied with the actions taken by the authorities.

\section{Thoughts and opinions}

A total of $152 / 414$ respondents $(36.7 \%$, 95\% CI 32\%$41 \%)$ somewhat or strongly believed that gender-based harassment contributes to the large gender disparity in orthopedic surgery. The rates for women and men were 68/117 (58.1\%, 95\% CI 49\%-67\%) and 84/296 (28.4\%, $95 \%$ CI $23 \%-33 \%$ ), respectively. Only 76/412 respondents $(18.4 \%, 95 \%$ CI $15 \%-22 \%)$ somewhat or strongly believed that sexual harassment contributes to the large
Table 2 (part 1 of 2). Prevalence of gender-based and sexual harassment reported by Canadian orthopedic surgeons

\begin{tabular}{|c|c|}
\hline Item & $\begin{array}{l}\% \text { of } \\
\text { respondents } \\
(95 \% \mathrm{Cl})\end{array}$ \\
\hline \multicolumn{2}{|l|}{ Gender-based harassment } \\
\hline Overall $(n=433)$ & $76(72-80)$ \\
\hline Men $(n=310)$ & $68(63-73)$ \\
\hline Women $(n=122)$ & $98(95-100)$ \\
\hline $\begin{array}{l}\text { Have you ever been in a situation where a supervisor, } \\
\text { colleague or patient treated you "differently" because of your } \\
\text { gender (i.e., mistreated, slighted or ignored you)? }(n=432)\end{array}$ & $32(28-36)$ \\
\hline Men $(n=309)$ & $12(8-16)$ \\
\hline Women $(n=122)$ & $84(77-91)$ \\
\hline $\begin{array}{l}\text { Have you ever been in a situation where a supervisor, } \\
\text { colleague or patient told offensive jokes or remarks? }(n=433)\end{array}$ & $70(66-74)$ \\
\hline Men $(n=310)$ & $65(60-70)$ \\
\hline Women $(n=122)$ & $85(79-91)$ \\
\hline $\begin{array}{l}\text { Have you ever been in a situation where a supervisor, } \\
\text { colleague or patient made sexist comments or displayed sexist } \\
\text { materials (such as suggesting that people of your gender are } \\
\text { not suited for the kind of work you do)? }(n=432)\end{array}$ & $37(32-42)$ \\
\hline Men $(n=309)$ & $21(16-26)$ \\
\hline Women $(n=122)$ & $78(71-85)$ \\
\hline $\begin{array}{l}\text { Have you ever been in a situation where a supervisor, } \\
\text { colleague or patient put you down or was condescending to } \\
\text { you because of your gender? }(n=431)\end{array}$ & $20(16-24)$ \\
\hline Men $(n=309)$ & $5(3-7)$ \\
\hline Women $(n=121)$ & $67(59-75)$ \\
\hline $\begin{array}{l}\text { Have you ever been in a situation where a supervisor, } \\
\text { colleague or patient suggested that you don't act how } \\
\text { someone of your gender is supposed to act? }(n=429)\end{array}$ & $15(12-18)$ \\
\hline Men $(n=307)$ & $4(2-6)$ \\
\hline Women $(n=121)$ & $41(32-50)$ \\
\hline $\begin{array}{l}\text { Have you ever been in a situation where you felt you received } \\
\text { an inferior learning/work experience owing to your gender } \\
\text { (such as fewer opportunities or being held to a higher standard } \\
\text { than your peers of other genders)? ( } n=431 \text { ) }\end{array}$ & $18(14-22)$ \\
\hline $\operatorname{Men}(n=308)$ & $5(3-7)$ \\
\hline Women $(n=122)$ & $49(40-58)$ \\
\hline \multicolumn{2}{|l|}{ Sexual harassment } \\
\hline Overall $(n=423)$ & $74(70-78)$ \\
\hline Men $(n=303)$ & $71(66-76)$ \\
\hline Women $(n=119)$ & $83(76-90)$ \\
\hline \multicolumn{2}{|l|}{ Verbal/psychologic } \\
\hline Overall $(n=423)$ & $72(68-76)$ \\
\hline Men $(n=303)$ & $69(64-74)$ \\
\hline Women $(n=119)$ & $80(73-87)$ \\
\hline $\begin{array}{l}\text { Have you ever been in a situation where a supervisor, } \\
\text { colleague or patient made crude sexual remarks? }(n=423)\end{array}$ & $64(59-69)$ \\
\hline Men $(n=303)$ & $62(57-67)$ \\
\hline Women $(n=119)$ & $68(60-76)$ \\
\hline $\begin{array}{l}\text { Have you ever been in a situation where a supervisor, } \\
\text { colleague or patient attempted to establish a romantic sexual } \\
\text { relationship with you despite your attempts to discourage him/ } \\
\text { her (such as continuing to ask you for dates, drinks, dinner, } \\
\text { etc., even though you said "No")? ( } n=422)\end{array}$ & $17(13-21)$ \\
\hline Men $(n=302)$ & $15(11-19)$ \\
\hline Women $(n=119)$ & $23(15-31)$ \\
\hline $\begin{array}{l}\text { Have you ever been in a situation where a supervisor, } \\
\text { colleague or patient gave you unwanted attention (such as } \\
\text { whistles, calls, suggestive looks, gestures or body language)? } \\
(n=422)\end{array}$ & $22(18-26)$ \\
\hline $\operatorname{Men}(n=302)$ & $15(11-19)$ \\
\hline Women $(n=119)$ & $40(32-49)$ \\
\hline
\end{tabular}




\begin{tabular}{|c|c|}
\hline Item & $\begin{array}{l}\% \text { of } \\
\text { respondents } \\
(95 \% \mathrm{Cl})\end{array}$ \\
\hline $\begin{array}{l}\text { Have you ever been in a situation where a supervisor, } \\
\text { colleague or patient told suggestive stories or displayed } \\
\text { suggestive materials? ( } n=422 \text { ) }\end{array}$ & $24(20-28)$ \\
\hline Men $(n=302)$ & $20(15-25)$ \\
\hline Women $(n=119)$ & $32(24-40)$ \\
\hline $\begin{array}{l}\text { Have you ever been in a situation where a supervisor, } \\
\text { colleague or patient made inappropriate sexual comments } \\
\text { about your appearance or body? }(n=422)\end{array}$ & $19(15-23)$ \\
\hline Men $(n=303)$ & $11(7-15)$ \\
\hline Women $(n=119)$ & $42(33-51)$ \\
\hline $\begin{array}{l}\text { Have you ever been in a situation where you felt you were } \\
\text { being subtly bribed with some sort of reward (e.g., preferential } \\
\text { treatment) to engage in sexual behaviour with a supervisor, } \\
\text { colleague or patient? }(n=420)\end{array}$ & $1(0-2)$ \\
\hline Men $(n=300)$ & $0(0-0)$ \\
\hline Women $(n=119)$ & $4(0-8)$ \\
\hline $\begin{array}{l}\text { Have you ever been in a situation where a supervisor, } \\
\text { colleague or patient made you feel threatened with some sort } \\
\text { of retaliation for not being sexually cooperative (such as by } \\
\text { mentioning an upcoming review)? }(n=419)\end{array}$ & $1(0-2)$ \\
\hline Men $(n=301)$ & $0(0-0)$ \\
\hline Women $(n=117)$ & $3(0-7)$ \\
\hline $\begin{array}{l}\text { Have you ever been in a situation where you actually } \\
\text { experienced negative consequences for refusing to engage in } \\
\text { sexual activity with a supervisor, colleague or patient? }(n=420)\end{array}$ & $1(0-2)$ \\
\hline Men $(n=301)$ & $0(0-0)$ \\
\hline Women $(n=118)$ & $4(0-8)$ \\
\hline $\begin{array}{l}\text { Have you ever been in a situation where a supervisor or colleague } \\
\text { made you feel afraid you would be treated poorly in your learning/ } \\
\text { work environment if you didn't sexually cooperate? }(n=422)\end{array}$ & $1(0-2)$ \\
\hline Men $(n=302)$ & $0(0-0)$ \\
\hline Women $(n=119)$ & $3(0-6)$ \\
\hline $\begin{array}{l}\text { Have you ever been in a situation where a supervisor or } \\
\text { colleague implied faster promotions or better treatment in your } \\
\text { learning/work environment if you were sexually cooperative? } \\
(n=420)\end{array}$ & $1(0-2)$ \\
\hline Men $(n=300)$ & $1(0-2)$ \\
\hline Women $(n=119)$ & $3(0-6)$ \\
\hline \multicolumn{2}{|l|}{ Physical } \\
\hline Overall $(n=422)$ & $23(19-27)$ \\
\hline Men $(n=303)$ & $16(12-20)$ \\
\hline Women $(n=119)$ & $41(32-50)$ \\
\hline $\begin{array}{l}\text { Have you ever been in a situation where a supervisor, } \\
\text { colleague or patient made physical contact that made you feel } \\
\text { uncomfortable (such as hugs, shoulder rubs or getting too } \\
\text { close)? }(n=420)\end{array}$ & $20(16-24)$ \\
\hline Men $(n=300)$ & $12(8-16)$ \\
\hline Women $(n=119)$ & $39(30-48)$ \\
\hline $\begin{array}{l}\text { Have you ever been in a situation where a supervisor, } \\
\text { colleague or patient made unwanted attempts to stroke, } \\
\text { fondle or kiss you? ( } n=421 \text { ) }\end{array}$ & $8(5-11)$ \\
\hline Men $(n=301)$ & $5(3-7)$ \\
\hline Women $(n=119)$ & $13(7-19)$ \\
\hline $\begin{array}{l}\text { Have you ever been in a situation where a supervisor, } \\
\text { colleague or patient unsuccessfully attempted to have sex } \\
\text { with you without your consent or against your will? ( } n=419)\end{array}$ & $3(1-5)$ \\
\hline Men $(n=300)$ & $5(3-7)$ \\
\hline Women $(n=118)$ & $6(2-10)$ \\
\hline $\begin{array}{l}\text { Have you ever been in a situation where a supervisor, colleague } \\
\text { or patient had sex with you without your consent or against your } \\
\text { will? ( } n=422 \text { ) }\end{array}$ & $1(0-2)$ \\
\hline Men $(n=303)$ & $0(0-0)$ \\
\hline Women $(n=119)$ & $3(0-6)$ \\
\hline $\mathrm{Cl}=$ confidence interval. & \\
\hline
\end{tabular}

gender disparity in orthopedic surgery. The rates for women and men were $26 / 116$ (22.4\%, 95\% CI 15\%-30\%) and 50/295 (16.9\%, 95\% CI 13\%-22\%), respectively.

\section{Risk factors for gender-based and sexual harassment}

Multiple logistic analyses showed that women were significantly more likely than men to experience both gender-based harassment and sexual harassment (OR 16.2, 95\% CI 4.854.0, and OR 2.2, 95\% CI 1.2-4.0, respectively) (Table 3). Being nonwhite was associated with a reduced risk of experiencing gender-based harassment (OR 0.5, 95\% CI 0.3-0.99), but no association was found in relation to sexual harassment. The risk of gender-based or sexual harassment was not significantly associated with age, marital status, current career stage or geographic location of residency.

\section{Discussion}

As the global demand for equity among genders and races within the workplace intensifies, it is crucial to explore the possibility of gender-based and sexual harassment as contributors to the enduring gender gap in orthopedic surgery. ${ }^{8,9} \mathrm{We}$ found a high prevalence of gender-based harassment and sexual harassment in the field of orthopedic surgery in Canada, with $76 \%$ and $74 \%$ of respondents, respectively, reporting having experienced at least 1 occurrence. Women were 16.2 times more likely than men to report experiencing an instance of gender-based harassment and 2.2 times more likely to report experiencing an instance of sexual harassment. Respondents identifying as nonwhite had a reduced risk of experiencing gender-based harassment (OR 0.5). More than one-third (37\%) of respondents believed that gender-based harassment contributes to the prevailing gender disparity in orthopedic surgery.

Our findings differ from those of other investigators who have studied discrimination, bullying, sexual harassment and harassment in orthopedic surgery. In a survey of surgeons in Australasia, of the orthopedic surgeons who completed the survey ( $41 \%$ response rate), $15 \%$ reported discrimination, $32 \%$ reported bullying, $3 \%$ reported sexual harassment, and $15 \%$ reported harassment, some of the lowest proportions reported of all surgical specialties surveyed. ${ }^{14}$ The authors did not specifically target the specialty of orthopedic surgery and did not evaluate between-gender differences within each subspecialty, which prevents a direct comparison with our study.

Moreover, a recent survey on discrimination, bullying, sexual harassment and harassment distributed to women and underrepresented minority members of the American Academy of Orthopaedic Surgeons (AAOS) showed that $79 \%$ of members had been exposed to discrimination, $55 \%$ had been exposed to bullying, $47 \%$ had been exposed to sexual harassment, and $40 \%$ had been exposed to harassment. ${ }^{15}$ Female AAOS members were more likely than 
Table 3. Multiple logistic regression analysis of risk factors for gender-based and sexual harassment

\begin{tabular}{|c|c|}
\hline Variable & OR $(95 \% \mathrm{Cl})$ \\
\hline \multicolumn{2}{|c|}{ Gender-based harassment } \\
\hline Age & $0.99(0.97-1.02)$ \\
\hline \multicolumn{2}{|l|}{ Gender } \\
\hline Man & Ref \\
\hline Woman & $16.18(4.85-53.99)$ \\
\hline \multicolumn{2}{|l|}{ Race/ethnicity } \\
\hline White & Ref \\
\hline Nonwhite & $0.52(0.27-0.99)$ \\
\hline \multicolumn{2}{|l|}{ Martial status } \\
\hline Married & Ref \\
\hline Single & $1.14(0.42-3.13)$ \\
\hline Other & $0.53(0.25-1.13)$ \\
\hline \multicolumn{2}{|c|}{ Current occupation } \\
\hline Staff & Ref \\
\hline Resident & $3.73(0.55-4.92)$ \\
\hline Fellow & $1.65(0.36-3.10)$ \\
\hline Retired & $1.06(0.34-1.79)$ \\
\hline \multicolumn{2}{|c|}{ Residency education } \\
\hline Canada & Ref \\
\hline Elsewhere & $1.55(0.60-3.97)$ \\
\hline \multicolumn{2}{|c|}{ Sexual harassment } \\
\hline Age & $1.01(0.98-1.03)$ \\
\hline \multicolumn{2}{|l|}{ Gender } \\
\hline Man & Ref \\
\hline Woman & $2.18(1.19-4.01)$ \\
\hline \multicolumn{2}{|l|}{ Race/ethnicity } \\
\hline White & Ref \\
\hline Nonwhite & $0.98(0.53-1.84)$ \\
\hline \multicolumn{2}{|l|}{ Martial status } \\
\hline Married & Ref \\
\hline Single & $0.94(0.44-2.01)$ \\
\hline Other & $0.99(0.47-2.07)$ \\
\hline \multicolumn{2}{|c|}{ Current occupation } \\
\hline Staff & Ref \\
\hline Resident & $0.65(0.28-1.54)$ \\
\hline Fellow & $1.46(0.53-4.03)$ \\
\hline Retired & $1.42(0.60-3.39)$ \\
\hline \multicolumn{2}{|c|}{ Residency education } \\
\hline Canada & Ref \\
\hline Elsewhere & $3.23(0.93-11.20)$ \\
\hline
\end{tabular}

male members to report having experienced sexual harassment (54\% v. $10 \%)$. However, discrimination and harassment that were explicitly gender-based were not investigated. Furthermore, the survey had a very low response rate, and, owing to selective sampling, the data collected did not represent the experiences of all AAOS members. ${ }^{15}$

In contrast to our survey, both the survey of surgeons in Australasia and the survey of minority AAOS members did not ask about respondents' experiences of specific discrimination, bullying, sexual harassment and harassment behaviours before the prevalence of these behaviours was quantified. The difference in these measurement tools may explain some of the variation between our results and previous findings of harassment and discrimination in the field of orthopedic surgery. To our knowledge, our survey is the first to evaluate the prevalence of specific gender-based and sexual harassment behaviours in an entire orthopedic society and to relate findings to the persistent gender imbalance in orthopedic surgery.

Research in other medical specialties has also shown a high prevalence of gender-based harassment and genderbased discrimination. In a recent survey conducted among members of an international gynecologic society, $25 \%$ of physicians reported experiencing nonsexual workplace harassment. ${ }^{16}$ Among these harassment victims, $85 \%$ of females cited gender harassment as the most common form of harassment, compared to $58 \%$ of males. Similarly, a survey in the field of cardiology showed that $96 \%$ of female respondents reported discrimination based on gender, compared to only $8 \%$ of males. ${ }^{17}$ This survey also highlighted the concern that discrimination based on gender within cardiology has continually increased in both the female and male populations since 1996.

Our finding of a reduced risk of experiencing genderbased harassment for nonwhite respondents is interesting. Previous research in Australasia showed that race was the most frequent form of discrimination among surveyed surgeons. ${ }^{14}$ This difference in findings may be related to multicultural differences between Canada and Australasia.

Surveys of other medical specialties have shown a high prevalence of sexual harassment in the workplace, with stark differences among genders. Brown and colleagues ${ }^{16}$ found that $28 \%$ of gynecologic physicians reported an experience of sexual harassment in the workplace, with females significantly more likely than males to be the victims. In a survey conducted among vascular surgery trainees, $47 \%$ of respondents reported having been sexually harassed, with rates of $67 \%$ for women and $37 \%$ for men. ${ }^{18}$ These gender differences were similarly observed among cardiothoracic surgeons, with $81 \%$ of women and $46 \%$ of men reporting any form of sexual harassment. ${ }^{19}$ Our observed overall prevalence rates of sexual harassment in the workplace for both female $(83 \%)$ and male $(71 \%)$ orthopedic surgeons were higher than rates reported for other medical professions.

Stratton and colleagues ${ }^{6}$ found that women were 2.2 times more likely than men to choose a medical specialty program based on concerns surrounding gender discrimination and sexual harassment. Furthermore, a recent survey of Canadian Federation of Medical Students members showed that incidents of sexual harassment faced by students were deeply personal and internalized, which may have led to further deterrence from specialties with a high prevalence of sexual harassment..$^{20}$ As is evident in the current study, the field of orthopedic surgery in Canada has a remarkably high prevalence of gender-based and sexual harassment, particularly for women, and more than 1 in 3 respondents believed that this could be a factor contributing to the large gender disparity in the field. 


\section{Limitations}

Although we addressed personal email invitations directly to the intended recipient in an attempt to increase response rates, the overall response rate, $26 \%$, was low. However, it is important to note the difference in the response rate between the genders: $48 \%$ for women and $22 \%$ for men. People who received the questionnaire may have felt that the topic was not relevant to them, as they may never have experienced gender-based or sexual harassment and consequently chose not to participate in the study (response bias). Therefore, our results may overestimate the prevalence of gender-based and sexual harassment. Conversely, concerns about survey anonymity and being identified as a victim of gender-based or sexual harassment may have deterred some people from completing the questionnaire, leading to a bias of underreporting. Furthermore, as a response was not required for every question, there were missing and incomplete data, which may have resulted in a response bias for reporting specific gender-based or sexual harassment behaviours.

\section{Conclusion}

The prevalence of gender-based and sexual harassment is high in the field of orthopedic surgery. Women are more likely to report experiencing an occurrence of gender-based or sexual harassment than men, which may be contributing to the stagnation of female representation in the field. Future research could expand this study to other national orthopedic societies in order to investigate the prevalence of gender-based and sexual harassment internationally and identify the behavioural basis of harassment. Our results may provide the impetus for orthopedic societies to develop action plans and to re-examine and enforce policies that would address these damaging behaviours appropriately.

Affiliations: From the Department of Surgery, McMaster University, Hamilton, Ont. (Giglio, Schneider, Bond, Madden, McKay, Bozzo, Bhandari); the Research Institute, St. Joseph's Healthcare Hamilton, Hamilton, Ont. (Madden); the Department of Health Research Methods, Evidence, and Impact, McMaster University, Hamilton, Ont. (Bhandari); and the Juravinski Hospital and Cancer Centre, Hamilton Health Sciences, Hamilton, Ont. (Ghert).

Competing interests: Kim Madden reports a grant from St. Joseph's Healthcare Foundation and personal fees from OrthoEvidence, outside the submitted work. Mohit Bhandari reports grants from the Canadian Institutes of Health Research (Foundation Grant 148388), National Institutes of Health, Physicians' Services Incorporated Foundation and US Department of Defense, and personal fees from PendoPharm, Bioventus and Acumed, outside the submitted work. Michelle Ghert reports grants from the Canadian Institutes of Health Research (Operating Grant 137104), Canadian Cancer Society and Hamilton Academic Health Sciences Organization, and personal fees from Wright Medical Group and Amgen, outside the submitted work. No other competing interests were declared.

Contributors: All authors designed the study. V. Giglio and P. Schneider acquired the data, which V. Giglio, P. Schneider, K. Madden, P. McKay and M. Ghert analyzed. V. Giglio, P. Schneider, Z. Bond, K. Madden and M. Ghert wrote the manuscript, which V. Giglio, P. Schneider, P. McKay, A. Bozzo, M. Bhandari and M. Ghert critically revised. All authors gave final approval of the article to be published.
Content licence: This is an Open Access article distributed in accordance with the terms of the Creative Commons Attribution (CC BY-NC-ND 4.0) licence, which permits use, distribution and reproduction in any medium, provided that the original publication is properly cited, the use is noncommercial (i.e., research or educational use), and no modifications or adaptations are made. See: https://creativecommons.org/licenses/by-nc-nd/4.0/.

\section{References}

1. Policy on preventing sexual and gender-based harassment. Ontario Human Rights Commission; 2013. Available: http://www.ohrc.on.ca/ en/policy-preventing-sexual-and-gender-based-harassment-0 (accessed 2018 Mar. 6).

2. Sexual harassment. Government of Canada; 2019. Available: https:// www.canada.ca/en/employment-social-development/services/labour -standards/reports/sexual-harassment.html (accessed 2020 Feb. 20).

3. Global strategy on human resources for health: Workforce 2030. Geneva: World Health Organization; 2015. Available: https://apps. who.int/iris/bitstream/handle/10665/250368/9789241511131-eng.pdf? sequence $=1$ (accessed 2019 Nov. 13).

4. Jagsi R, Griffith KA, Jones R, et al. Sexual harassment and discrimination experiences of academic medical faculty. FAMA 2016;315:2120-1.

5. Huang Y, Chua TC, Saw RP, et al. Discrimination, bullying and harassment in surgery: a systematic review and meta-analysis. World $\mathcal{f}$ Surg 2018;42:3867-73.

6. Stratton TD, McLaughlin MA, Witte FM, et al. Does students' exposure to gender discrimination and sexual harassment in medical school affect specialty choice and residency program selection? Acad Med 2005;80:400-8.

7. Physicians in Canada, 2017. Ottawa: Canadian Institute for Health Information; 2019. Available: https://www.deslibris.ca/ID/10100535 (accessed 2019 Nov. 13).

8. Lewis VO, Scherl SA, O'Connor MI. Women in orthopaedics way behind the number curve. F Bone foint Surg Am 2012;94:e30.

9. Miller EK, LaPorte DM. Barriers to women entering the field of orthopedic surgery. Orthopedics 2015;38:530-3.

10. Number and percent distribution of physicians by specialty and sex, Canada 2018. Ottawa: Canadian Medical Association; 2018. Available: https://www.cma.ca/sites/default/files/2019-03/2018-06-spec -sex.pdf (accessed 2019 Nov. 13).

11. Fitzgerald LF, Gelfand MJ, Drasgow F. Measuring sexual harassment: theoretical and psychometric advances. Basic Appl Soc Psychol 1995; 17:425-45.

12. Fitzgerald LF, Magley VJ, Drasgow F, et al. Measuring sexual harassment in the military: the Sexual Experiences Questionnaire (SEQ-DoD). Mil Psychol 1999;11:243-63.

13. Survey on Sexual Misconduct in the Canadian Armed Forces. Statistics Canada; 2016. Available: http://www23.statcan.gc.ca/imdb/p3Instr.pl? Function=assembleInstr\&a=1\&\&lang=en\&Item_Id=285179 (accessed 2018 Mar. 6).

14. Crebbin W, Campbell G, Hillis DA, et al. Prevalence of bullying, discrimination and sexual harassment in surgery in Australasia. ANZ 7 Surg 2015;85:905-9.

15. Samora JB, Van Heest A, Weber K, et al. Harassment, discrimination, and bullying in orthopaedics: a work environment and culture survey. 7 Am Acad Orthop Surg 2020:28:e1097-104.

16. Brown J, Drury L, Raub K, et al. Workplace harassment and discrimination in gynecology: results of the AAGL member survey. $f$ Minim Invasive Gynecol 2019;26:838-46.

17. Lewis SJ, Mehta LS, Douglas PS, et al. Changes in the professional lives of cardiologists over 2 decades. 7 Am Coll Cardiol 2017;69:452-62.

18. Nukala M, Freedman-Weiss M, Yoo P, et al. Sexual harassment in vascular surgery training programs. Ann Vasc Surg 2020;62:92-7.

19. Ceppa DP, Dolejs SC, Boden N, et al. Sexual harassment and cardiothoracic surgery: \#UsToo? Ann Thorac Surg 2020;109:1283-8.

20. Phillips SP, Webber J, Imbeau S, et al. Sexual harassment of Canadian medical students: a national survey. EClinicalMedicine 2019;7:15-20. 